of a field which has not been synthesized in this way before and on making it fascinating reading. They are also to be thanked for proving to all those reviewers, librarians and readers, who by now must inevitably have become cynical about the flood of symposium proceedings and other edited collections now being published, that such a work can be worth more than the enormous price which has to be paid for it.

I. W. WHTMSTER

\section{DEVELOPMENTAL IMMUNOLOGY}

\section{Immunology and Development}

Edited by Matteo Adinolfi. (Clinies in Developmental Medicine, No. 34.) Pp. 187. (Spastics International, in association with Heinemann (Medical): London, 1969.) $63 s$.

'IHIs slim volume, approaching developmental immunology from many directions, is an interesting blend of fact and fantasy. Opening with Talmage's expert account of clonal selection it presonts the reader with moro hypotheses per page than is usual, even in immunology. Adinolfi and Wood then contribute a thorough and elegant chapter on the ontogeny of immunoglobulins and complement in man, providing a lucid and factual account of thoir important research which is likely to be of consider. able interest to clinician and pure seientist alike. The following chapter is more provocative. Written by Clem and Leslie, it is an entcrtaining review of present know. ledge of the phylogeny of the immune response. Starting with speculation on irnmune mechanisms in plants, these authors climb the evolutionary ladder in a thorough and very readable way, pausing inevitably at the hagfish. Although pleasing to hear from them that the standards of hagfish husbandry havo been improved it is saddening to be told that this fine and nuble crcature has been deposed from its pinnacle in immunology. It seems that it can reject skin allografts after all.

The influence of the late David Kirby on devclopmental immunology is clearly emphasized in tho chapter by Billington on the basic immunological enigma of pregnancy. Why is the foetus not rejected as an allograft? No complete answer is available, but in revicwing the possibilities $\mathrm{DI}_{\mathrm{I}}$ Billington communicates the fascination of this problem. One can perhaps quibble with minor details of terminology, always a topic for disagrcement among immunologists. The word hornograft, a misnorner, is now obsolete. "The term "maternal tolerance" is used several times. The phenomenon it describes is not immunological tolerance in the classical sense and it would seem safer to substitute some other expression. Billington also incorrectly assumes that the transplantability of human choriocarcinoma in a xenogeneic host implies the absence of transplantation antigens from the tumour.

A chapter by Hobbs reviews the causes of primary immune paresis in man and, although almost unreadable, it is a powerhouse of condensed factual information which could become a very useful source of reference for practis. ing clinical immunologists and paediatricians. McConnell, in the final chapter, concentrates on another clinical aberration of immunology and dovelopment, incompatibilities of red cell, white cell and platelet antigens between foetus and mother. He provides a suitably optimistic note by emphasizing the preventability of $\mathrm{Rh}$ sensitization with anti-D serum.

The wide range of subjects covered and the varicty of approaches to them illustrate both the fascination and clinical importance of developmental immunology. Whether one is concerned with the immunology of development or the devolopment of immune responses this book is worth reading. Dr Adinolfi has assembled it with care. It is short, well produced and appears in a very handsome jacket.

G. A. Curait

\section{INTIMATE RELATIONS}

\section{Parasitism and Symbiology}

An Introductory 'Text. By Clark 1'. Read. Pp. vii +316. (Ronald Press: Now York, 1970.) n.p.

THe word symbiosis can have several meanings and Dr Read uses it in this book to describe the intimate interrclations between different species of organisms irrespective of whether the association is harmful or not. l'arasitism is thereforo considered as a form of symbiosis.

Parasitism is a way of life common to many plant, animal and microbial groups, but for historical reasons the phenomenon is rarely studied as a single entity. The aim of the book is to cut across artificial boundaries and to demonstrate the basic principles of the topic. In order to do this, examples are chosen from bactcria, viruses and parasitic fungi as well as protozoa and helminths. While this is entirely laudable, the broadth of the subject and interdisciplinary approach are probably too great for a singlo author to do full justice to all aspects of the subject. The coverage in some chapters is therefore uneven. Indeed, the preponderance of matcrial in the book as a whole reflects the author's interest in parasitic protozoa and helminths. The chapter on the genetics of symbiosis, whero mierobes aro adequately covered, mercly underlines the scarcity of information on helrninths.

The initial chapters are concerned with definitions, particularly the problems of defining the term discases Lifo cycles are presented in the guise of adaptations for reaching hosts, and readers will recognize much that is already familiar in the chapter. There is a need for an entirely new approach to the dynamies of the life cycle, and the description of life cycles in torms of open feed-back loops which are closed by the host could be further developed. In this context, the recent use of systems analysis to study tho epiderniology of a sheep-nematodo host-parasite system is given full treatment.

The sections on adaptations for establishment in the host, nutrition, and metabolism are the best in the book, reflecting the most active areas of research in recent years.

The final chapter, symbiology and human affairs, gives an unusual insight into the impact of parasites on civilization, from the plagues of the middle agos to schistosomiasis and malaria, both so important today. The principal conclusion of this chapter is that parasitic diseasos will be with us in the foreseeable future because of the plastic nature of the interaction between host and symbiote and the continual appearance of drug resistant strains or virulent mutations.

The gencral level of the text makes this a book for the undorgraduate rather than the specialist. The layout of the book is clear with numerous subheadings and excellent: illustrations. Above all, the text is very readable.

\section{R. A. WILSON}

\section{X-RAY DIFFRACTION}

\section{An Introduction to X-ray Crystallography}

By M. M. Woolfson. Pp. ix +380 . (Cambridge University Press: London, March 1970.) 85s; $\$ 13.50$.

The number of textbooks on $\mathrm{X}$-ray diffraction is increasing rapidly, and each one now has to justify itself in some spocial way if it is to become generally accepted. This book falls clearly into the catcgory of an introductory work; it ties the principles of the subject to the basic physies that the undergraduate will have learnt, and it gives enough detail for the new rosearch student to cope with the procedures that he will be faced with. It avoids the peril of including so much theory that the neweomer to the subject will feel overwhelmed. The 